\title{
Nutritional Value of Cladodes and Fruits of Prickly Pears (Opuntia ficus-indica)
}

\author{
Heba R. Elshehy', Sally S. El Sayed ${ }^{2}$, Abdel-Mawla, E.M. ${ }^{3}$, Neveen F. Agamy ${ }^{4}$ \\ 1 Department of Nutrition, Faculty of Allied Medical Sciences, Pharos University in Alexan- \\ dria, Egypt \\ 2 Faculty of Allied Medical Sciences, Pharos University, Alexandria, Egypt \\ 3 Aquaculture Research Center, Arab Academy for Science, Technology and Maritime Trans- \\ port, Egypt \\ 4 High Institute of Public Health, Alexandria University, Egypt .
}

Received: 24 February, 2020

Revised: 8 April, 2020

Accepted: 3 May, 2020

\begin{abstract}
Prickly pear (Opuntia ficus-indica), have been used for centuries as food and forage resources. The purpose of this study was to assess some of the nutritional value of their cladodes and fruit. Fruit juice contained phenolic compounds concentration of 119.66 and $123.56 \mathrm{mg} / 100 \mathrm{~g}$ and antioxidant activity of $40.38 \%$ and $39.18 \%$, respectively. Appreciable amounts of vitamin C being 15.94 and $26.76 \mathrm{mg} / 100 \mathrm{~g}$, and the amount of vitamin E were 1.37 and $96.80 \mu \mathrm{g} / 100 \mathrm{~g}$, respectively. Regard to vitamin D, it was not detected in the cladode while the fruit contained $1.40 \mu \mathrm{g} / 100 \mathrm{~g}$. The amount of beta-carotene ( $\beta$-carotene) were 57.51 and 28.01 $\mu \mathrm{g} / 100 \mathrm{~g}$ for cladodes and fruit, respectively. The major fatty acids of the cladode and fruit were unsaturated fatty acids, mainly linoleic acid (omega-6), linolenic acid (omega-3) and oleic acid (omega-9). The main identified saturated fatty acids were palmitic and stearic acids. The present study demonstrated that cladodes and fruits of prickly pears can be considered as functional food due to their valuable contents of fibers, vitamins, fatty acids, phenolic compounds and antioxidants.
\end{abstract}

Key words: prickly pears, fruit, antioxidant activity, vitamins, fatty acids, phenolics.

\section{INTRODUCTION}

Environmental changes are one of the major challenges facing the world nowadays and in the future. Many countries, especially in Africa and Asia, are facing extended droughts and desertification. To overcome these circumstances, the crops have to survive water scarcity, elevated temperatures and inadequate soils. (Inglese et al., 2017). Opuntia species are known to have an extraordinary capacity to store water and great capacity to withstand extreme environments established to be stressful for most plant species. They are widely used to prevent soil erosion and to combat desertification. Furthermore, it can deal with global environmental changes such as the elevation in atmospheric $\mathrm{CO}_{2}$ levels. Opuntia species have been used for centuries as food and forage resources and in traditional folk medicine for their nutritional properties and their benefit in chronic diseases. Additionally, they have been cultivated as ornamental plants (Scalisia et al., 2015, Slimen et al., 2016, Díaz et al., 2017).
Prickly pears belong to the dicotyledon angiosperm Cactaceae family. Prickly pears is a tropical and subtropical plant, it can grow in dry climates, it is geographically distributed in Mexico, South Africa and Mediterranean countries including Egypt (El-Mostafa et al., 2014). Two parts of the plant are consumed as food: the fruits and the nopal pad or cladodes (Osuna-Martínez et al., 2014). Prickly pears are a beneficial source of dietary fibers and bioactive phytochemical compounds, they can be consumed as an essential source of natural antioxidants therefor it is considered a functional food. Their antioxidant activity can guard against the oxidative cellular damage (Osuna-Martínez et al., 2014).

Prickly pears have been traditionally used for their medicinal values, such as controlling diabetes, arteriosclerosis, asthma, burns and gastritis (López-Romero et al., 2014, Hwang et al., 2017). Epidemiological studies have demonstrated that regular consumption of plant-based food has the 
ability to become the future of primary prevention of many chronic diseases related to oxidative stress (Feugang et al., 2006, AbdEl-Razek \& Hassan, 2011).

Nutritional constituents of prickly pears vary in different countries, these variations may be due to geographical location, soil, climatic conditions and maturation (Chinedu et al., 2017). The purpose of the current study was to highlight the nutritional value of cladode and fruit prickly pears cultivated in Egypt.

\section{MATERIALS AND METHODS}

The experimental study was conducted at the Nutrition Laboratory, High Institute of Public Health, Alexandria University, Egypt.

\section{Plant Materials and Preparation}

Cladodes and fruits of prickly pears were purchased from a local market in Alexandria, Egypt during the summer season. Cladodes were washed, thorns were removed and crushed by a grinder then squeezed using muslin cloth to produce the extract (Galati et al., 2003). The whole fresh fruits were sorted, washed with tap water, manually peeled then the juice was extracted from the whole edible pulp using a food processor and strained with no addition of water (Abd El-Razek \& Hassan, 2011).

\section{Chemical analysis}

\section{Proximate composition}

Moisture, total ash, crude protein, crude fat, crude fiber and total carbohydrate (calculated by difference) contents of prickly pears cladode extract and fruit juice were determined according to the methods described by the Association of Official Analytical Chemists (AOAC., 2005).

\section{Total phenolic content}

Prickly pears cladode extract and fruit juice samples were extracted with $80 \%$ acetone using a sonication bath for $25 \mathrm{~min}$. The resultant solution was centrifuged for $10 \mathrm{~min}$ at $6040 \mathrm{xg}$ and the supernatant was used. The total phenolic content was estimated according to the Folin-Ciocalteu method according to the method described by Pakade et al. (2013). Gallic acid was used as the calibration standard and the results were recorded as gallic acid equivalents (mg/100 $\mathrm{g}$ of extract).

\section{Total antioxidant activity}

The DPPH (2,2-diphenyl-1-picryl-hydrazylhydrate) free radical scavenging activity assay was estimated by the method described by Pakade et al (2013), the results were reported as a percentage of the DPPH concentration left in solution. Ascorbic acid was used as a positive control.

\section{Vitamins content}

The samples of prickly pears cladodes extract and fruit juice were homogenized with an extracting solution containing meta-phosphoric acid and acetic acid. The extracts were used to estimate the vitamin C content using High Performance Liquid Chromatography (HPLC) analytical assay, Hewlett Packard HPLC series 1100 with acetonitrile-water (50:50) as the mobile phases with flow rate of 1.5 $\mathrm{ml} / \mathrm{min}$, the detection was done at $254 \mathrm{~nm}$ according to the method described by Ismail \& Fun (2003). Vitamin C content was expressed as $\mathrm{mg} / 100 \mathrm{~g}$.

Vitamins $\mathrm{E}, \mathrm{D}$ and $\beta$-carotene contents in prickly pears cladode extract and fruit juice, extracted using $n$-hexane. The extracts were used for determining vitamins $\mathrm{E}, \mathrm{D}$ and $\beta$-carotene using HPLC analytical assay according to the method described by Qian and Sheng (1998) and Kozlov et al. (2003). Vitamins E, D and $\beta$-carotene contents were expressed as $\mu \mathrm{g} / 100 \mathrm{~g}$.

\section{Fatty acid profile}

Methanolic sulphuric acid and benzene were used for lipid methylation. Fatty acid profile of prickly pears cladodes extract and fruit juice were determined according to the method of Egan et al. (1981) using Gas Liquid Chromatography (GLC) analytical assay by Hewlett Packard (HP) 6890 GC, with Flame Ionization Detector (FID). The column phase was HP-88 (88\%-Cyanopropyl-aryl-polysiloxane), $100 \mathrm{~m}, 0.25 \mathrm{~mm}$ ID, $0.2 \mu \mathrm{m}$ film thickness, Nitrogen was used as a carrier gas with flow rate of $1 \mathrm{ml} / \mathrm{min}$. The injector temperature was $220^{\circ} \mathrm{C}$. The results were expressed as fatty acids percentages. Finally, the calculated sums and ratios were; total monounsaturated fatty acids content (इMUFA), total polyunsaturated fatty acids content ( $\Sigma$ PUFA), total unsaturated fatty acids content ( $\Sigma$ UFA), total saturated fatty acids ( $\Sigma$ SFA), $\Sigma$ PUFA/ $\Sigma$ SFA $(\mathrm{P} / \mathrm{S})$ ratio, $\Sigma$ UFA $/ \Sigma$ SFA ratio and $\omega-6 / \omega-3$ ratio.

\section{Statistical analysis}

Data were fed to the computer using IBM SPSS software package version 20. Quantitative 
data were described using mean and standard deviation (mean $\pm \mathrm{SD}$ ). (Ali and Bhaskar, 2016)

\section{RESULTS AND DISCUSSION}

\section{Proximate composition}

The results in Table (1) show the proximate composition of prickly pears cladodes and fruits. The moisture content of the cladodes extract was $87.01 \%$ which is within the range reported by the Food and Agriculture Organization (FAO, 2001) as $80-95 \%$, and agreed well with the results of Snyman (2004) and Díaz et al. (2017). Conversely, Méndez et al (2015) and Rocchetti et al. (2018) reported slightly higher moisture content as $92.33 \%$ and $94.0 \%$, respectively. The moisture content of the fruit juice was $88.6 \%$ which is within the range reported by Feugang et al (2006) as $84 \%-90 \%$, this value agrees with the results reported by Bariza et al. (2017) as $87.07 \%$. A lower value of $82.2 \%$ was obtained by Medina et al. (2007).

The ash is an indicator of the mineral contents. Minerals play crucial roles in the body as increasing metabolic processes and enhancing growth and development (Otuna et al., 2016). The ash content of the cladode extract as shown in Table (1) was $2.97 \%$. This value is higher than that reported by El-Safy (2013) and Rocchetti et al. (2018) as $1.85 \%$ and $0.50 \%$, respectively. On the other hand, this value is slightly lower than the content of $3.33 \%$ reported by Chinedu et al. (2017). The total ash content in the fruit juice shown in Table (1) was $0.32 \%$, which agrees with the previous studies (Medina et al., 2007, Kamble et al., 2017). In contrast, this result is lower than the values reported by Méndez et al. (2015) and Asma et al. (2017) who reported that the ash contents were $2.45 \%$ and $1.05 \%$, respectively.

As shown in Table (1) the crude protein content of cladodes extract was $1.39 \%$. Different pre- vious studies reported that the protein content of prickly pears cladodes ranged between $0.5-1 \%$ (Díaz et al., 2017, Rocchetti et al., 2018). On the other hand, this result is extremely higher than the value reported in previous studies being $0.14 \%$ (Abdessemed et al., 2014). The obtained result is lower than that reported by El-Safy (2013) who found that the protein content was $2.64 \%$. The data obtained in the present study show that the protein content of prickly pears fruit juice was $5.6 \%$. The obtained result is higher than the results obtained from previous studies (Chougui et al., 2013, Méndez et al., 2015, Kamble et al., 2017). They reported that the protein content of the fruit juice ranged between 0.2 and $2 \%$. The results in Table (1) generally indicated that the fruits are higher in proteins than the cladode.

Table (1) shows that the crude fat content of the prickly pears cladodes extract was $0.11 \%$. These data agree with Rocchetti et al.(2018) who reported that the fat content was $0.12 \%$. On the other hand, this result is lower than the value reported by El-Safy (2013) as $0.87 \%$. The current data show that the fat content of the fruit was $0.22 \%$, which is nearly similar to that reported by Chiteva and Wairagu (2013) Kamble et al. (2017) as $0.4 \%$ and 0.09 , respectively.

The crude fiber content of the prickly pears cladodes extract was $4.14 \%$. This value is higher than the results reported by Rocchetti et al. (2018) as $3.42 \%$. Other studies reported that the crude fiber content of the cladodes was 1-2\% (Feugang et al., 2006, Díaz et al., 2017). The crude fiber content of the fruit juice was $1.44 \%$. This value shown in Table (1) is nearly similar to that reported by Chiteva \& Wairagu (2013) as $1.37 \%$. A slightly higher result was obtained by Méndez et al. (2015) as 2.5\%. On the other hand, the result of the present study was extremely higher than that reported by Sawaya et al. (1983) as $0.02 \%$. Also, the fibers content of

Table 1: Proximate chemical composition of cladodes and fruits of prickly pears.

\begin{tabular}{lcccccc}
\hline Sample & $\begin{array}{c}\text { Moisture } \\
\text { content } \\
\text { Mean } \pm \text { SD } \\
(\mathbf{\%})\end{array}$ & $\begin{array}{c}\text { Total ash } \\
\text { Mean } \pm \text { SD } \\
\mathbf{( \% )}\end{array}$ & $\begin{array}{c}\text { Crude protein } \\
\text { Mean } \pm \text { SD } \\
\mathbf{( \% )}\end{array}$ & $\begin{array}{c}\text { Crude fat } \\
\text { Mean } \pm \text { SD } \\
\mathbf{( \% )}\end{array}$ & $\begin{array}{c}\text { Crude fibers } \\
\text { Mean } \pm \text { SD } \\
(\%)\end{array}$ & $\begin{array}{c}\text { Total carbohy- } \\
\text { drates* } \\
\text { Mean } \pm \text { SD } \\
(\%)\end{array}$ \\
\hline Cladode extract & $87.01 \pm 7.91$ & $2.97 \pm 0.231$ & $1.39 \pm 0.105$ & $0.11 \pm 0.016$ & $4.14 \pm 0.436$ & $8.52 \pm 0.836$ \\
Fruit juice & $88.6 \pm 8.02$ & $0.32 \pm 0.056$ & $5.6 \pm 0.521$ & $0.22 \pm 0.018$ & $1.44 \pm 0.013$ & $5.26 \pm 0.567$ \\
\hline
\end{tabular}

Values represent the mean of three replicates \pm standard deviation (SD) on fresh weight

* calculated by difference. 
the cladode is higher than that of the fruits.

Table (1) demonstrated that the total carbohydrates content of cladode extract was $8.52 \%$. Díaz et al. (2017) reported that carbohydrate content was 3-7\%, Rocchetti et al. (2018) reported lower carbohydrate content of $3.05 \%$. Inglese et al. (2017) reported that the fruit juice of O. ficus-indica contained 4-6\% of carbohydrates. According to this figure, the fruits are rich in carbohydrates being $50-75 \%$ of the dry matter. The total carbohydrate content of the fruit juice was $5.26 \%$, OsunaMartínez et al. (2014) reported that carbohydrate content was (3-7\%). On the other hand, Feugang et al. (2006) reported it as $12-17 \%$.

\section{Total phenolic content}

Recently, a great deal of attention has been paid for polyphenols due to their antioxidant activity, which is concerned in several health benefits such as the prevention of inflammation, cardiovascular and neurodegenerative diseases. Polyphenols have also shown anticancer activity (El-Mostafa et al., 2014). The data in Table (2) show that the content of the phenolics in cladode extract of prickly pears was $119.66 \mathrm{mg} / 100 \mathrm{~g}$. This result is markedly lower than that reported by Ayadi et al. (2009) as $900 \mathrm{mg} / 100 \mathrm{~g}$. The phenolic content of the fruit juice was $123.56 \mathrm{mg} / 100 \mathrm{~g}$. Chougui et al. (2013) reported that total phenolics varied in different cultivars of prickly pears and ranged from 47.23 to $66.60 \mathrm{mg} / 100 \mathrm{~g}$.

\section{Antioxidant activity}

Recently, much attention has been focused on the use of plant materials as natural antioxidants which can effectively replace synthetic antioxidant. It is assumed to protect humans from oxidative cell damages, resulting in the protection against several diseases (Dib et al., 2013, Rocchetti et al., 2018). The data in Table (2) show the total antioxidants activity of prickly pears cladodes extract and fruit juice. Antioxidants activity of cladodes extract was $40.38 \%$. This result is extremely higher than that obtained by Astello-Garcia et al. (2015) as 12.7\% and that of Rocchetti et al. (2018) as 0.104\%. On the contrary, other previous studies of Chaouch et al. (2016) showed higher values (54.52\%-78.93\%) and that of Du-Toit et al. (2018) as 83.77-95.53\%. Fruit juice had antioxidants activity of $39.18 \%$. This result is within the ranges reported by Chaouch et al. (2016) as 46.32\%- 64.08\% and that of Alsaad et al. (2019) as 36.5-78.1\%. Conversely, the result of the present study is higher than that reported by Abd El-Razek \& Hassan (2011) and Mabrouki et al. (2015) as $28.68 \%$ and $11.54 \%$, respectively.

\section{Vitamins content}

The data in Table (2) show that vitamin C (ascorbic acid) content in the cladodes is 15.94 $\mathrm{mg} / 100 \mathrm{~g}$, the obtained result is within the range that was reported by Slimen et al. (2016) and Kamble et al. (2017) as 7-22 mg/100 g, and is higher than the results reported by Inglese et al. (2017) as $11 \mathrm{mg} / 100 \mathrm{~g}$. On the other hand, it is lower than the result of Fernández-López et al. (2010) as 18.5 $\mathrm{mg} / 100 \mathrm{~g}$. Fruit juice was found to contain vitamin $\mathrm{C}$ at varying levels. It is considered as a valuable source of ascorbic acid. Inglese et al. (2017) found that the vitamin $\mathrm{C}$ content of prickly pear fruit juice varied from $24.1-28.0 \mathrm{mg} / 100 \mathrm{~g}$. Toplu et al. (2009) reported that prickly pear fruits exhibit a vitamin C content of 18.04 to $37.31 \mathrm{mg} / 100 \mathrm{~g}$ fresh weight, and Slimen et al. (2016) reported that it ranged from 1 to $48 \mathrm{mg} / 100 \mathrm{~g}$. vitamin C content in the present study was $26.76 \mathrm{mg} / 100 \mathrm{~g}$, which lies within the previously reported ranges, and agrees well with that reported by Tesoriere et al. (2004) as $29 \mathrm{mg} / 100 \mathrm{~g}$.

Vitamin E, was detected in the cladodes extract as shown in (Table 2) being $1.37 \mu \mathrm{g} / 100 \mathrm{~g}$. On the other hand, it was not detected in other previous studies according to El-Mostafa et al. (2014) and Kamble et al. (2017). Prickly pear fruit juice contained $96.8 \mu \mathrm{g} / 100 \mathrm{gm}$ vitamin $\mathrm{E}$. This result is higher than that reported by Tesoriere et al. (2004) as $80 \mu \mathrm{g} / 100 \mathrm{~g}$. On the other hand, Abd El-Razek

Table 2: Phenolic content, antioxidant activity, and some vitamins content of cladodes and fruits of prickly pears.

\begin{tabular}{lcccccc}
\hline & $\begin{array}{c}\text { Phenolic con- } \\
\text { tent }(\mathbf{m g} / \mathbf{1 0 0} \mathbf{g})\end{array}$ & $\begin{array}{c}\text { Antioxidant } \\
\text { Activity } \mathbf{( \% )}\end{array}$ & $\begin{array}{c}\text { Vitamin C } \\
(\mathbf{m g} / \mathbf{1 0 0} \mathbf{g})\end{array}$ & $\begin{array}{c}\text { Vitamin E } \\
(\boldsymbol{\mu g} / \mathbf{1 0 0} \mathbf{g})\end{array}$ & $\begin{array}{c}\text { Vitamin D } \\
(\boldsymbol{\mu g} / \mathbf{1 0 0} \mathbf{g})\end{array}$ & $\begin{array}{c}\boldsymbol{\beta}-\mathrm{Carotene} \\
(\boldsymbol{\mu g} / \mathbf{1 0 0} \mathbf{g})\end{array}$ \\
\hline Cladode extract & 119.66 & 40.38 & 15.94 & 1.37 & $\mathrm{ND}$ & 57.51 \\
Fruit juice & 123.56 & 39.18 & 26.76 & 96.80 & 1.40 & 28.01 \\
\hline
\end{tabular}

ND: not detected. 
et al. (2012) reported higher results $(125 \mu \mathrm{g} / 100$ g). Vitamin D was not detected in cladodes extract while fruit juice contained $1.40 \mu \mathrm{g} / 100 \mathrm{~g}$ vitamin D. These results cannot be compared with previous results since none of the researchers measured vitamin D content in prickly pear cladodes or fruits in their studies. The absence of the two fat soluble vitamins; namely $\mathrm{E}$ and $\mathrm{D}$ is expected due to the very low content of fat in both of the cladodes and the fruit, as shown in Table (1).

Beta carotene is a precursor of vitamin A and is changed in the body to vitamin A which is needed for healthy eyes and skin. Epidemiological studies have shown that high intakes of carotenoid-rich fruits and vegetables and high blood levels of $\beta$-carotene are associated with decreased incidence of some cancers because of its antioxidant properties and help eliminating the free radicals from the body (Toplu et al., 2009). The $\beta$-carotene content of cladode extract as shown in Table (2) was $57.51 \mu \mathrm{g} / 100$ $\mathrm{g}$, which lies within the previous reported range of Slimen et al. (2016) as 47-77 $\mu \mathrm{g} / 100 \mathrm{~g}$, and was higher than that reported by Shedbalkar et al. (2010) as 11.3-53.5 $\mu \mathrm{g} / 100 \mathrm{~g}$. On the other hand, Feugang et al. (2006) stated that $\beta$-carotene is not detected in cladodes in their study. As regards prickly pears fruits, the $\beta$-carotene content was $28.01 \mu \mathrm{g} / 100 \mathrm{~g}$, which agreed with the result of Shedbalkar et al. (2010) as $29.9 \mu \mathrm{g} / 100$ $\mathrm{g}$ and is nearly similar to Abd El-Razek et al (2012) as $17.54 \mu \mathrm{g} / 100 \mathrm{~g}$, which are ext tremely higher than the previous studies in which $\beta$-carotene ranged from $1.2-3 \mu \mathrm{g} / 100$ g. (Fernández-López et al., 2010, Slimen et al. 2016, Kamble et al., 2017).

\section{Fatty acid profile}

The data in Table (3) demonstrated that fatty acids of crude fat extracted from the cladodes were found to be rich source of the unsaturated fatty acids, representing $69.24 \%$ of the total fatty acids content (monounsaturated $24.24 \%$, and polyunsaturated $45.00 \%$ ). While, the saturated fatty acids constituted $30.76 \%$. The main unsaturated fatty acids were linoleic acid (omega-6), linolenic acid (omega-3) and oleic acid (omega-9) with 24.81, 20.19 and $10.39 \%$, respectively. The main saturated fatty acids include palmitic and stearic acids with levels of 7.53 and $6.96 \%$, respectively. These results are in accordance with those of El-Mostafa et al. (2014) who mentioned that the results of linoleic acid, linolenic acid and oleic acid were 34.87 , 33.23 and $11.16 \%$, respectively, while palmitic acid was $13.87 \%$. The fatty acid profile of prickly pear fruit juice showed that the unsaturated fatty acids were more predominant (59.91\%), while saturated fatty acids were $40.09 \%$. Of the unsaturated fatty acids, linoleic acid was the dominating fatty acid, followed by linolenic acid, and oleic acid as $19.46 \%, 16.75 \%$, and $16.36 \%$, respectively. While, saturated fatty acids were, palmitic acid (15.36\%) followed by stearic acid (5.33\%). Previous studies on prickly pear showed a similar pattern (Ramadan \& Mörsel, 2003, El-Mostafa et al., 2014).

The presence of high amount of the essential

Table 3: The Fatty acids profile of cladodes and fruits of prickly pears

\begin{tabular}{|c|c|c|}
\hline Fatty acids profile & $\begin{array}{c}\text { Cladode } \\
(\%)\end{array}$ & $\begin{array}{c}\text { Fruit } \\
(\%)\end{array}$ \\
\hline \multicolumn{3}{|l|}{ Poly unsaturated fatty acids } \\
\hline Linolenic acid (C18:3 $\alpha / \omega-3)$ & 20.19 & 16.75 \\
\hline Linoleic acid $(\mathrm{C} 18: 2 \mathrm{c} / \omega-6)$ & 24.81 & 19.46 \\
\hline \multicolumn{3}{|l|}{ Mono unsaturated fatty acids } \\
\hline Oleic acid $(\mathrm{C} 18: 1 \mathrm{c} / \omega-9)$ & 10.39 & 16.36 \\
\hline Myristoleic acid (C14:1) & 2.41 & 5.32 \\
\hline Cis-10-Pentadecenoic acid (C15:1) & 3.21 & 0.15 \\
\hline Palmitoleic acid (C16:1) & 1.86 & 1.14 \\
\hline Cis-11-Ecosenoic acid (C20:1) & 6.36 & 0.73 \\
\hline \multicolumn{3}{|l|}{ Saturated fatty acids } \\
\hline Palmitic acid (C16:0) & 7.53 & 15.36 \\
\hline Stearic acid (C18:0) & 6.96 & 5.33 \\
\hline Undecanoic acid (C11:0) & ND & 0.83 \\
\hline Lauric acid (C12:0) & ND & 2.15 \\
\hline Tridecanoic acid (C13:0) & 4.96 & 5.38 \\
\hline Myristic acid (C14:0) & 2.24 & 4.94 \\
\hline Pentadecanoic acid (C15:0) & 5.47 & 3.30 \\
\hline Heptadecanoic acid (C17:0) & 2.71 & 2.80 \\
\hline Arachidic acid (C20:0) & 0.90 & ND \\
\hline Total monounsaturated fatty acids ( $\Sigma$ MUFA) & 24.23 & 23.70 \\
\hline Total polyunsaturated fatty acids ( $\mathrm{P}$ PUFA) & 45.00 & 36.21 \\
\hline Total unsaturated fatty acids ( $\Sigma$ UFA) & 69.23 & 59.91 \\
\hline Total saturated fatty acids ( $\Sigma$ SFA) & 30.77 & 40.09 \\
\hline$\Sigma \mathrm{PUFA} / \Sigma \mathrm{SFA}(\mathrm{P} / \mathrm{S})$ ratio & 1.46 & 0.90 \\
\hline$\Sigma \mathrm{UFA} / \Sigma \mathrm{SFA}$ ratio & 2.25 & 1.49 \\
\hline$\omega-6 / \omega-3$ ratio & 1.23 & 1.16 \\
\hline
\end{tabular}

ND: not detected. $\omega$ : omega, $\mathrm{P} / \mathrm{S}$ ratio: polyunsaturated/saturated ratio 
fatty acids suggested that this prickly pears cladodes extract and fruit juice are highly nutritious due to the ability of unsaturated oils to reduce serum cholesterol. Linoleic acid is an essential fatty acid that cannot be synthesized by the body and is a precursor of arachidonic acid biosynthesis, it is one of the most important polyunsaturated fatty acids in human food due to its hypocholesterolemic effects and its role in preventing distinct heart vascular diseases. It was also described to be very essential for brain development (Otuna et al., 2016).

The ratio of unsaturated to saturated fatty acids of the cladodes extract was 2.25; this result is quite close to other previous studies of López-Cervantes et al (2011) and El-Safy (2013). While that of the fruit juice was 1.49 , that agrees well with the result of Ramadan \& Mörsel, (2003).

These recorded differential levels of the nutritional content of prickly pears could be attributed to climatic variations, geographical location, coupled with soil condition and the level of fertilization. (Food and Agriculture Organization of the United Nations, 2001, Chinedu et al., 2017)

\section{CONCLUSION}

The current study revealed that prickly pears cladodes and fruits can be considered as functional food due to their valuable contents of fibers, vitamin C, fatty acids, phenolic compounds and antioxidants activity.

\section{REFERENCES}

AbdEl-Razek, F., El-Metwally, E., Shehab, G., Hassan, A. \& Gomaa, A. 2012. Effects of cactus pear (Opuntia ficus-indica) juice on oxidative stress in diabetic cataract rats. Saudi Journal for Health Sciences, 1: 23-29.

AbdEl-Razek, F. \& Hassan, A. 2011. Nutritional value and hypoglycemic effect of prickly cactus pear (Opuntia ficus-indica) fruit juice in alloxan-induced diabetic rats. Australian Journal of Basic and Applied Sciences, 5: 356-377.

Abdessemed, D., Nezari, M., Mohamed, R., Abdessemed, D., Bahadi, F. \& Halitim, A. 2014. Emulsifying effect of pectin from Opuntia ficus-indica cladode. Journal of Chemical and Pharmaceutical Research, 6: 198-201.

Ali, Z. \& Bhaskar, B. 2016. Basic statistical tools in research and data analysis. Indian Journal of Anaesthesia, 60: 662-669.

Alsaad, A., Altemimi, A., Aziz, S. \& Lakhssassi, N. 2019. Extraction and identification of cactus Opuntia dillenii seed oil and its added value for human health benefits. Pharmacognosy Journal, 11: 579-587.

AOAC. 2005. Official Method of Analysis. 17th ed. Association of Official Analytical Chemists. Gaithersburg Maryl, USA.

Astello-García, M., Cervantes, I., Nair, V., Santos-Díaz, M., Reyes-Agüero, A., Guéraud, F., Negre-Salvayre, A., Rossignol, M., Cisneros-Zevallos, L. \& Barba-delaRosa, A. 2015. Chemical composition and phenolic compounds profile of cladodes from Opuntia spp. cultivars with different domestication gradient. Journal of Food Composition and Analysis, 43: 119-130.

Ayadi, M., Abdelmaksoud, W., Ennouri, M. \& Attia, H. 2009. Cladodes from Opuntia ficusindica as a source of dietary fiber: Effect on dough characteristics and cake making. Industrial Crops and Products, 30: 40-47.

Bariza, A.T. \& Yassine, N. 2017. Algerian prickly pear (Opuntia ficus-indica L.) physicochemical characteristics. International Journal of Scientific Research, 5: 14-17.

Chaouch, M., Hafsa, J., Rihouey, C., Le-Cerf, D. \& Majdoub, H. 2016. Effect of extraction conditions on the antioxidant and antiglycation capacity of carbohydrates from Opuntia robusta cladodes. International Journal of Food Science and Technology, 51: 929-937.

Chinedu, N., Benjamin, A. \& Peter, A. 2017. Chemical composition and physicochemical analysis of matured stems of Opuntia dillenii grown in Nigeria. Food Science and Technology, 5: 106-112.

Chiteva, R. \& Wairagu, N. 2013. Chemical and nutritional content of Opuntia ficus-indica (L.). African Journal of Biotechnology, 12: 33093312.

Chougui, N., Louaileche, H., Mohedeb, S., Mouloudj, Y., Hammoui, Y. \& Tamendjari, A. 2013. Physico-chemical characterisation and antioxidant activity of some Opuntia ficusindica varieties grown in North Algeria. African Journal of Biotechnology, 12: 299-307. 
Díaz, M., Rosa, A., Héliès-Toussaint, C., Guéraud, F. \& Nègre-Salvayre, A. 2017. Opuntia spp.: Characterization and benefits in chronic diseases. Oxidative Medicine and Cellular Longevity, 2017: 1-17.

Dib, H., Beghdad, C., Belarbi, M., Seladji, M. \& Ghalem, M. 2013. Antioxidant activity of phenolic compounds of the cladodes of Opuntia ficus-indica Mill. from Northwest Algeria. International Journal of Medicine and Pharmaceutical Sciences, 3: 147-158.

Du-Toit, A., De-Wit, M., Osthoff, G. \& Hugo, A. 2018. Antioxidant properties of fresh and processed cactus pear cladodes from selected Opuntia ficus-indica and O. robusta cultivars. South African Journal of Botany, 118: 44-51.

Egan, H., Kirk, R., Sawyer, R. \& Pearson, D. 1981. Pearson's chemical analysis of foods, Churchill Livingstone, London, Melboure, New York.

El-Mostafa, K., El-Kharrassi, Y., Badreddine, A., Andreoletti, P., Vamecq, J., ElKebbaj, M., Latruffe, N., Lizard, G., Nasser, B. \& Cherkaoui-Malki, M. 2014. Nopal Cactus (Opuntia ficus-indica) as a source of bioactive compounds for nutrition, health and disease. Molecules, 19: 14879-14901.

El-Safy, S. 2013. Evaluation and utilization of cladodes flour in formulating functional sponge cake. World Applied Sciences Journal, 27: 512-523.

Fernández-López, J., Almela, L., Obón, J. \& Castellar, R. 2010. Determination of antioxidant constituents in cactus pear fruits. Plant Foods for Human Nutrition, 65: 253-259.

Feugang, J., Konarski, P., Zou, D., Stintzing, F. \& Zou, C. 2006. Nutritional and medicinal use of Cactus pear (Opuntia spp.) cladodes and fruits. Frontiers in Bioscience, 11: 25742589.

Food and Agriculture Organization of the United Nations 2001. Cactus (Opuntia spp.) as Forage, Rome, FAO Plant Production and Protection Paper.

Galati, E., Tripodo, M., Trovato, A., Aquino, A. \& Monforte, M. 2003. Biological activity of Opuntia ficus-indica cladodes II: Effect on experimental hypercholesterolemia in rats. Pharmaceutical Biology, 41: 175-179.
Hwang, S., Kang, I. \& Lim, S. 2017. Antidiabetic effect of fresh nopal (Opuntia ficus-indica) in low-dose streptozotocin-induced diabetic rats fed a high-fat diet. Evidence-Based Complementary and Alternative Medicine, 2017:1-8.

Inglese, P., Mondragon, C., Nefzaoui, A. \& Sáenz, C. 2017. Crop Ecology, Cultivation and Uses of Cactus Pear, Rome, The Food and Agriculture Organization of the United Nations and the International Center for Agricultural Research in the Dry Areas.

Ismail, A. \& Fun, C. 2003. Determination of vitamin $C, \beta$-carotene and Riboflavin contents in five green vegetables organically and conventionally grown. Malaysian Journal of $\mathrm{Nu}-$ trition, 9: 31-39.

Kamble, S., Debaje, P., Ranveer, R. \& Sahoo, A. 2017. Nutritional Importance of Cactus: A Review. Trends in Biosciences, 10: 76687677.

Kozlov, É., Solunina, I., Lyubareva, M. \& Nadtochii, M. 2003. HPLC determination of vitamins $\mathrm{A}, \mathrm{D}$, and $\mathrm{E}$ in multivitamin compositions. Pharmaceutical Chemistry Journal, 37: 560- 562.

López-Cervantes, J., Sánchez-Machado, D., Campas-Baypoli, O. \& Bueno-Solano, C. 2011. Functional properties and proximate composition of cactus pear cladodes flours. Food Science and Technology, 31: 654-659.

López-Romero, P., Pichardo-Ontiveros, E., AvilaNava, A., Vázquez-Manjarrez, N., Tovar, A., Pedraza-Chaverri, J. \& Torres, N. 2014. The effect of nopal (Opuntia ficus-indica) on postprandial blood glucose, incretins, and antioxidant activity in Mexican patients with type 2 diabetes after consumption of two different composition breakfasts. Journal of the American Academy of Nutrition and Dietetics, 114: 1811-1818.

Mabrouki, L., Zougari, B., Bendhifi, M. \& Borgi, M. 2015. Evaluation of antioxidant capacity, phenol and flavonoid contents of Opuntia streptacantha and Opuntia ficus-indica fruits pulp. Nature \& Technology, 13: 1-8.

Medina, D., Rodriguez, R. \& Romero, D. 2007. Chemical characterization of Opuntia dillenii and Opuntia ficus-indica fruits. Food Chemistry, 103: $38-45$.

Méndez, L., Flores, F., Martín, J., Rodríguez-Rod- 
ríguez, E. \& Romero, C. 2015. Physicochemical characterization of cactus pads from Opuntia dillenii and Opuntia ficus-indica. Food Chemistry, 188: 393-398.

Osuna-Martínez, U., Reyes-Esparza, J. \& Rodríguez-Fragoso, L. 2014. Cactus (Opuntia ficus-indica): A review on its antioxidants properties and potential pharmacological use in chronic diseases. Natural Products Chemistry and Research, 2: 1-8.

Otuna, K., Yekeenb, T., Ajibolab, T. \& Bello, M. 2016. Phytonutrient contents of Opuntia ficus-indica L. stem grown in Nigeria. Jordan Journal of Chemistry, 11: 120-127.

Pakade, V., Cukrowska, E. \& Chimuka, L. 2013. Comparison of antioxidant activity of Moringa oleifera and selected vegetables in South Africa. South African Journal of Science, 109: 1-5.

Qian, H. \& Sheng, M. 1998. Simultaneous determination of fat-soluble vitamins $\mathrm{A}, \mathrm{D}$ and $\mathrm{E}$ and pro-vitamin D2 in animal feeds by one-step extraction and high-performance liquid chromatography analysis. Journal of Chromatography A, 825: 127-133.

Ramadan, M. \& Mörsel, J. 2003. Oil cactus pear (Opuntia ficus-indica L.). Food Chemistry, 82: 339-345.

Rocchetti, G., Pellizzoni, M., Montesano, D. \& Lucini, L. 2018. Italian Opuntia ficus-indica cladodes as rich source of bioactive compounds with health-promoting properties. Foods, 7: 1-12.

Sawaya, W., Khatchadourian, H., Safi, W. \& Al-
Hammad, H. 1983. Chemical characterization of prickly pear pulp, Opuntia ficus-indica, and the manufacturing of prickly pear jam. Journal of Food Technology, 18: 183193.

Scalisia, A., Morandi, B., Inglese, P. \& LoBianco, R. 2016. Cladode growth dynamics in Opuntia ficus-indica under drought. Environmental and Expperimental Botany, 122: 158-167.

Shedbalkar, U., Adki, V., Jadhav, J. \& Bapat, V. 2010. Opuntia and other cacti: applications and biotechnological insights. Tropical Plant Biology, 3: 136-150.

Slimen, I., Najar, T. \& Abderrabba, M. 2016. Opuntia ficus-indica as a source of bioactive and nutritional phytochemicals. Journal of Food and Nutrition Sciences, 4: 162-169.

Snyman, H. 2004. Effect of various water application strategies on root development of Opuntia ficus-indica and O. robusta under greenhouse growth conditions. Journal of the Professional Association for Cactus Development, 6: 35-61.

Tesoriere, L., Butera, D., Pintaudi, M., Allegra, M. \& Livrea, M. 2004. Supplementation with cactus pear (Opuntia ficus-indica) fruit decreases oxidative stress in healthy humans: a comparative study with vitamin C. American Journal of Clinical Nutrition, 80: 391-395.

Toplu, C., Serce, S., Ercisli, S., Kamiloglu, O. \& Sengul, M. 2009. Phenotypic variation in physico-chemical properties among cactus pear fruits (Opuntia ficus-indica (L.) Miller) from Turkey. Pharmacognosy Magazine, 5: 400-406. 


\section{القيمة الفذائية لأوراق وثمار التين الشوكي}

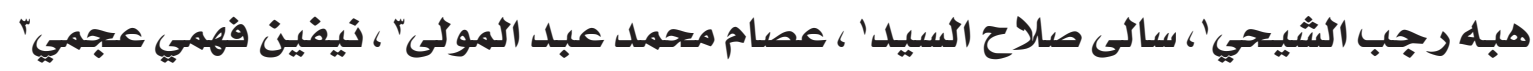

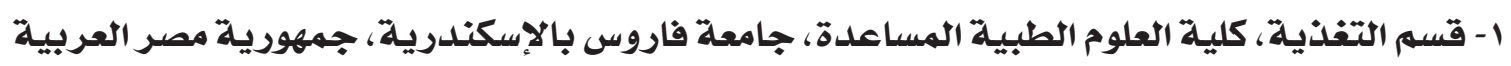

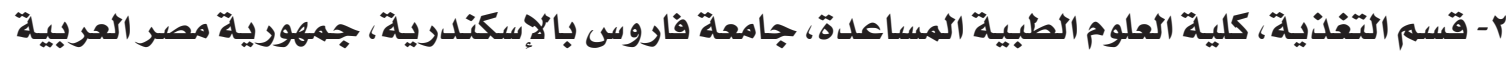

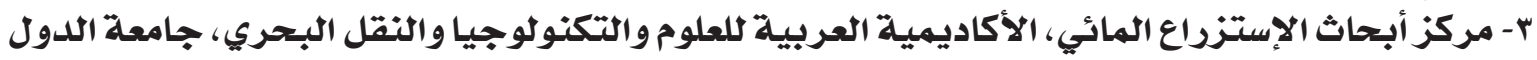

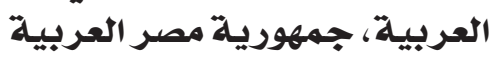
ع- قسم التغذية، المعهد العالي للصحة العية العامة، جامعة الإسكندرية، جمهورية مصر العربية تم استخدام التين الثوكي لعدة قرون في الغذاء والأعلاف. الغرض من هذه الدراسة هو تسليط الضوء

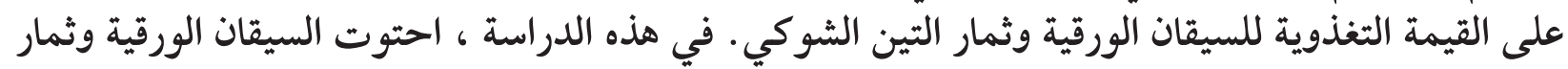

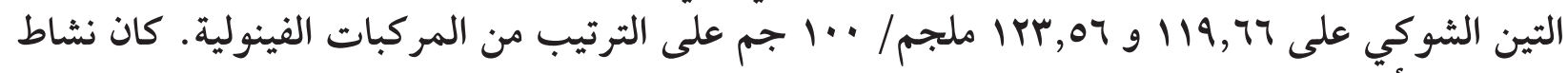

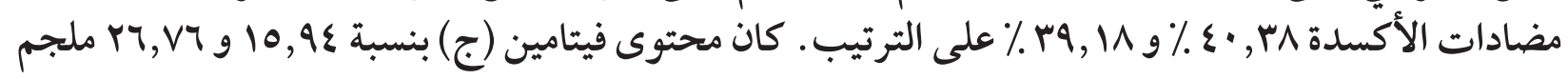

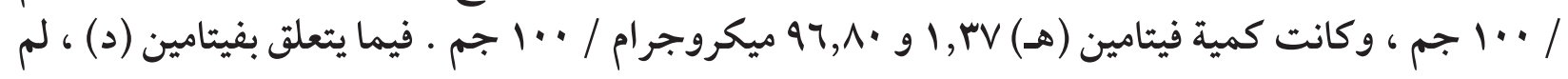

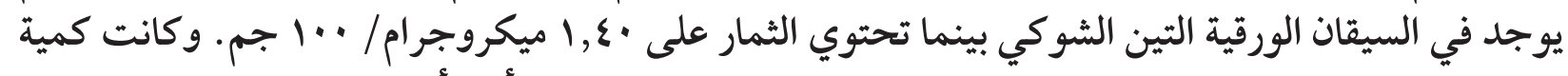

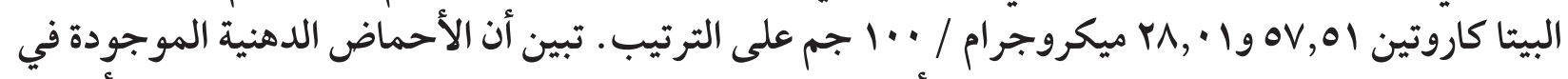

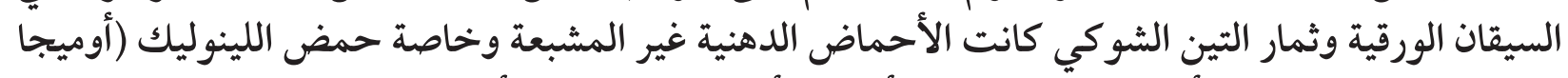

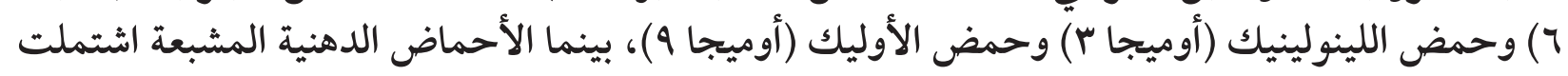

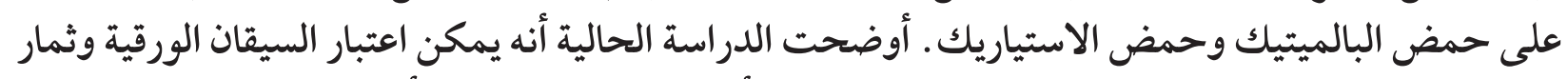

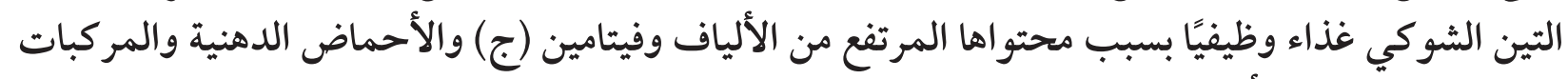
الفينولية ومضِادات الأكسدة. 
